\title{
ALPHA LIPOIC ACID INFLUENCE IN THE ATTENUATION OF OXIDATIVE STRESS AND OF CLINICAL MANIFESTATIONS OF NEUROPATHY IN DIABETES MELLITUS PATIENTS
}

\author{
Bondar Andrei Cristian¹, Popa Amorin Remus ${ }^{2,3}$ \\ 1. University of Oradea, Doctoral School of Biomedical Sciences, PhD student \\ 2. University of Oradea, Doctoral School of Biomedical Sciences, PhD coordinator \\ 3. Clinical County Emergency Hospital of Oradea, Internal Medicine II-Diabetology, \\ Head of Clinic
}

\begin{abstract}
Alpha lipoic acid is an antioxidant substance used for the pathogenic treatment of diabetic neuropathy, oxidative stress being a central mechanism in diabetic microvascular complications. Our study included 24 diabetes mellitus patients with diabetic neuropathy and 20 healthy subjects. Diabetes patients were given alpha lipoic acid $600 \mathrm{mg}$ intravenously for 10 days and then per os for 30 days.

Significant improvements were observed concerning oxidative stress evaluated by measuring serum malondyaldehide and ceruloplasmin. The clinical characteristic of neuropathy improved, both the level of pain decreased and the vibration perception threshold increased.

Our study demonstrated a two times higher level of oxidative stress in patients with diabetes compared to healthy subjects, and that by influencing oxidative stress we could influence the clinical aspects of neuropathy. Further investigations need to be done to explore the pleiotropic effects of alpha lipoic acid on other mechanisms that are implicated in the pathogenies of diabetic neuropathy.

Keywords: alpha lipoic acid, diabetic neuropathy, oxidative stress.
\end{abstract}

\section{Rezumat}

Acidul alfa lipoic este o substanță cu efect antioxidant utilizată în tratamentul patogenic al neuropatiei diabetice, stresul oxidativ fiind o componentă centrală în complicațiile microvasculare ale diabetului zaharat. Studiul pe care l-am efectuat a cuprins 24 de pacienți cu diabet zaharat și 20 de subiecți sănătoși.

Pacienților diabetici li s-a administrat acid alfa lipoic 600 mg intravenos timp de 10 zile, după care pe cale orală timp de 30 de zile. Au fost observate îmbunătățiri semnificative în parametrii care evaluează intensitatea stresului oxidativ, malondialdehida serică și ceruloplasmina serică. Caracteristicele clinice ale neuropatieei diabetice dureroase s-au îmbunătățit, atât nivelul durerii cât și pragul percepției vibratorii. 


\section{INTERNAL}

\section{Original papers}

Studiul a demonstrat că la pacienții cu diabet zaharat stresul oxidativ este de 2 ori mai puternic decât la subiecții sănătoși și că prin influențarea acestuia se pot influența caracteristicile clinice ale neuropatiei diabetice. Cercetări ulterioare sunt necesare pentru a evalua efectul pleiotropic al acidului alfa lipoic asupra celorlalte mecanisme care intervin în patogenia neuropatiei diabetice.

Cuvinte cheie: acidul alfa lipoic, neuropatie diabetică, stres oxidativ.

\section{Introduction}

Neuropathy represents the most frequent complication of diabetes mellitus, affecting sensitive, motor and vegetative nerves ${ }^{(1)}$. The prevalence of diabetic neuropathy is estimated to be approximately $50 \%$ after a 20 year history of diabetes ${ }^{(2)}$. Symmetric distal diabetic polyneuropathy represents $75 \%$ of the total number of diabetic neuropathies and constitute an element of gravity in the prognosis of the diabetic patient because it leads to foot ulcerations that frequently develop infection and often lead to amputation.

It is well known that diabetes mellitus represents the leading cause globally for non-traumatic limb amputation. Hyperglycaemia is the most important cause of increased oxidative stress in the diabetes patient, free radicals having the capacity to affect cellular membranes rich in lipids, with the generation of some products named lipoperoxides ${ }^{(3)}$. Oxidative stress represents one of the most important mechanisms for the apparition and progression of diabetic neuropathy because the free radicals determine an increase rate of apoptosis of the peripheral neurons.

The levels of these lipoperoxides can be easily identified by determining the level of malondialdehyde in the blood, a product generated by the lipoperoxidation of the polyunsaturated fatty acids from the cells membranes $^{(4)}$.

Data from literature demonstrates that diabetic patents have a three times higher malondialdehyde concentration in the blood than patients without diabetes ${ }^{(5)}$. In this context antioxidant therapy represents a necessity; one of the substances that showed promising results was alpha lipoic-acid (ALA), which determined in many studies a reduction in the symptomatology of diabetic neuropathy because it has scavenger effect on free radicals ${ }^{(6)}$. 


\section{Objectives}

The present study had the objective to evaluate the oxidative stress in diabetic patients compared to healthy controls, to determine the effect that alpha lipoic-acid possess on oxidative stress in patients with diabetes mellitus, to determine its effect on chronic pain that is characteristic for diabetic neuropathy and also on the vibration perception threshold.

\section{Material and method}

In the study were included 24 patients with type 1 or type 2 diabetes mellitus diagnosed with diabetic neuropathy being in evidence at the Regional Diabetes Centre Bihor and 20 patients without diabetes mellitus in evidence of a family physician from Oradea. Inclusion criteria were:

- patients that have given their consent for the participation in the study and for blood sampling

- patients with age over 18

- patients with type 1 or type 2 diabetes mellitus with a diagnosis for at least one year

- patients with diabetic neuropathy confirmed in the past by a neurologist

- patients that complained of lower limb pain consistent of diabetic neuropathy that has an intensity of at least 2 points on the visual analogue scale for pain, and the pain has a duration for at least one hour in the past three months

- patients that in the past 3 months were under the same antidiabetic medication

Exclusion criteria were:

- presence of neuropathy of another cause: metabolic diseases (uraemia, porphyria, hypothyroidism, hyperthyroidism), nutritional deficiencies, malabsorption, alcoholism, systemic diseases (systemic lupus erythematosus, sarcoidosis etc.), medication with toxic effects (chemotherapy, aminoglycosides, HIV therapy, colchicine, isoniazid, nitrofurantoin, amphotericin B ), chronic venous disease, infectious diseases (flu, mononucleosis, sepsis, HIV etc.)

- administration of antioxidant medication in the past 3 months

\section{Study design}

The study was a prospective, open, uncontrolled placebo, monocentric. The study has the purpose to compare oxidative stress in diabetic patients and healthy patients, to determine the efficacy of alpha lipoic-acid in improving pain in patients with diabetic neuropathy and in improving the vibration perception threshold, to determine the safety of alpha lipoic acid administration.

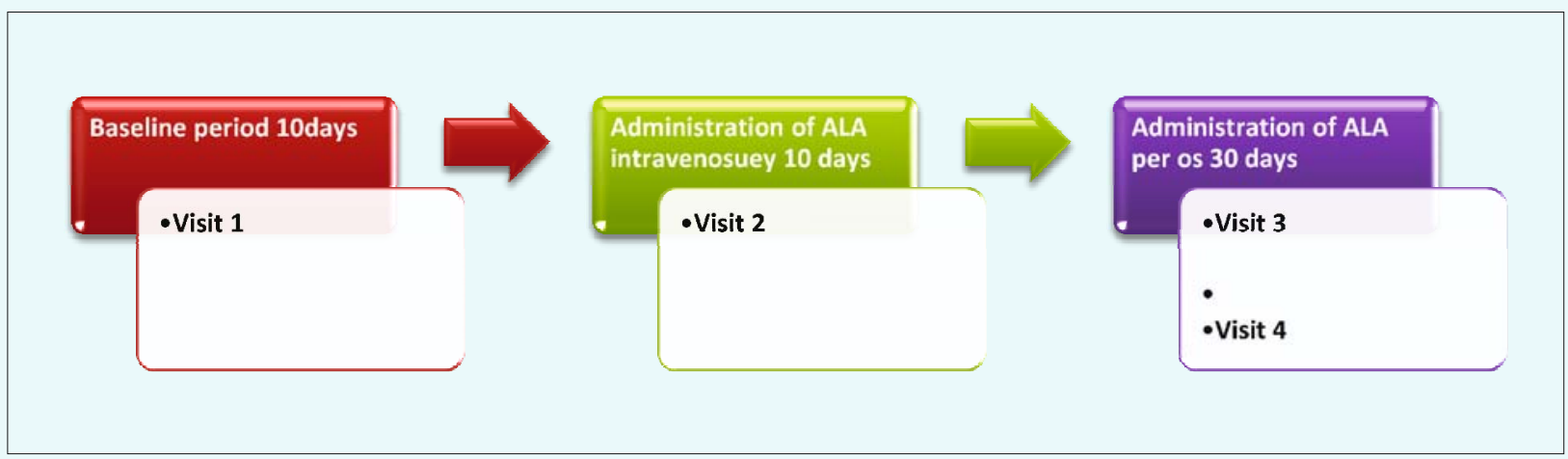

Figure 1. Study design 


\section{INTERNAL}

\section{Original papers}

The medication was administered for 10 days intravenously and then for 30 days by mouth. The study had a duration of 50 days.

The study was composed of the following phases:

- screening phase

- baseline phase

- therapeutic phase with a duration of 40 days when there was administered alpha lipoic acid for 10 days intravenously and then 30 days per os

- and the following visits:

- visit 1 (during the baseline period)

- visit 2 (before starting the administration of alpha lipoic acid intravenously)

- visit 3 (after finishing the administration of alpha lipoic acid intravenously and before starting the administration of alpha lipoic acid per os)

- visit 4 (after finishing the administration of alpha lipoic acid per os)

During the screening period were selected patients with diabetes mellitus and healthy subjects. Patients with diabetes were selected by the following method: the ones who presents at the Diabetes Clinic from the Clinical County Emergency Hospital for one day hospitalization every Monday during the month of May 2017 were verified if the fulfill the inclusion criteria and then they entered the study. Healthy subjects without diabetes mellitus were selected from a family's physician office from Oradea, with ages similar to that of diabetic patients.

During baseline period information was collected about the patients selected during the screening period:

- anamnesis

$\rightarrow$ demographic data: age, rural/urban environment, sex, education

$\rightarrow$ familial medical history

$\rightarrow$ personal medical history: diabetes mellitus type and duration, duration of presence of diabetic neuropathy, other comorbidities like high blood pressure, ischemic heart disease, myocardial infarction, liver disease, systemic inflammatory conditions, cancers

$\rightarrow$ medication administered in the past year

- physical examination

- measurement of blood pressure and heart rate

- preclinical examination: complete blood count, erythrocyte sedimentation rate, liver enzymes, urea, creatinine, glycated haemoglobin, triglycerides, LDLcholesterol, HDL -cholesterol, urine exam

\section{- EKG with 12 derivations}

There were selected 24 patients with diabetes mellitus and 20 healthy persons.

During treatment period alpha lipoic acid was administered intravenously and then per os 


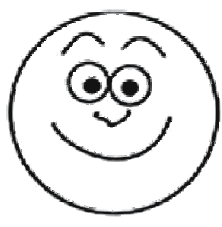

0 fără durere

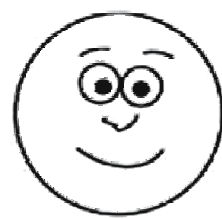

2

doare puțin

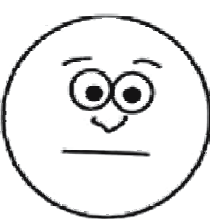

4

doare

mai mult

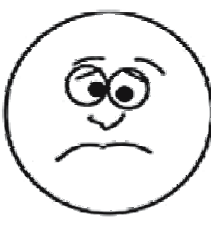

6

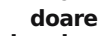

şi mai mult

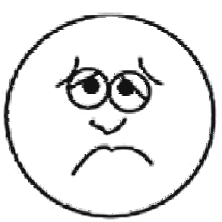

8

doare mult mai mult

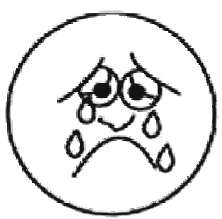

10

durere extrem

de puternică

Figure 2. Visual analogue pain scale

to the diabetic patients. The parameters analyses in the diabetic patients were:

- parameters that analyze the oxidative stress (evaluated during visit 2 and visit 4):

$\rightarrow$ determination of serum malondialdehyde a product that results during peroxidation of lipids, measured in $\mathrm{nmol} / \mathrm{ml}$

$\rightarrow$ determination of serum ceruloplasmin ceruloplasmin being considered an indicator of the oxidative stress, measured in $\mathrm{mg} / \mathrm{dl}$

- parameters for the assessment of the severity of diabetic neuropathy (during visits 2,3,4):

$\rightarrow$ pain intensity determined using the visual analogue scale for pain

$\rightarrow$ vibration perception threshold using the Rydel-Seiffer fork

Pain intensity was evaluated by a simple method with the help of the visual analogue pain scale, where the absence of pain was given a score of 0 and the extremely powerful pain was given a score of 10 . Also the scale has images attached that are very suggestive for the intensity of pain, the images presenting faces expressing the degree of discomfort. The patient indicated the intensity of pain that he felt during the previous day by choosing a number between 0 and 10 . This scale is easy to use regarding the educational level of the patient, being used worldwide for pain appreciation in different diseases.

Vibration perception threshold is a method that allows the appreciation of the vibratory sensitivity. By exploring vibratory sensitivity it can be proven the presence of a dysfunction of large sensitive nervous fibers. This investigation was performed using the calibrated Rydel-Seiffer fork. The patient was in resting position. Vibratory sensitivity is appreciated with the help of a triangle scale with divisions from 1 to 8 present on each arm of the Rydel-Seifer fork. The Reydel-Seiffer fork has two arms; there is a weight at the extremity of each arm. On one of the weights there is imprinted a black triangle and on another there is imprinted a white triangle. The arms are put into motion and start vibrating with a frequency of $64 \mathrm{~Hz}$. When the arms are vibrating the triangles give the examiner the illusion that they are double. The intersection between the two virtual triangles moves up the scale from gradation 0 to gradation 8 as the amplitude of oscillation reduces. The examiner observes the point of intersection between the two virtual triangles and the values is recorded when the patient does not feel the vibration anymore. Because the examination is subjective it was repeated and the mean values were calculated. 
Original papers

\begin{tabular}{|c|c|c|c|}
\hline Phase of study & Visit 1 & $\begin{array}{l}\text { Tests performed in patients } \\
\text { with diabetes mellitus }\end{array}$ & $\begin{array}{l}\text { Tests performed in } \\
\text { patients without } \\
\text { diabetes mellitus }\end{array}$ \\
\hline Screening phase & & $\begin{array}{l}\text { verification of fulfillment of } \\
\text { inclusion criteria and absence } \\
\text { of exclusion criteria }\end{array}$ & $\begin{array}{c}\text { verification of fulfillment } \\
\text { of inclusion criteria and } \\
\text { absence of exclusion } \\
\text { criteria }\end{array}$ \\
\hline Baseline phase & $\begin{array}{l}\text { Visit } 1 \text { - evaluation } \\
\text { of patients and } \\
\text { further verification } \\
\text { of inclusion criteria } \\
\text { fulfilment }\end{array}$ & $\begin{array}{c}\text { anamnesis, physical exam, } \\
\text { laboratory exams, glycated } \\
\text { hemoglobin determination, } \\
\text { EKG }\end{array}$ & $\begin{array}{c}\text { anamnesis, physical } \\
\text { exam }\end{array}$ \\
\hline $\begin{array}{l}\text { Intravenous } \\
\text { treatment phase }\end{array}$ & $\begin{array}{l}\text { Visit } 2 \text {-initiation of } \\
\text { treatment with ALA } \\
\text { intravenously }\end{array}$ & $\begin{array}{l}\text { blood level of lipoperoxids, } \\
\text { blood level of ceruloplasmin, } \\
\text { pain level determination using } \\
\text { the visual analogue pain scale, } \\
\text { vibration perception threshold } \\
\text { using the Rydel-Seiffer fork, } \\
\text { monitoring of adverse effects }\end{array}$ & $\begin{array}{l}\text { blood level of } \\
\text { lipoperoxids, blood level } \\
\text { of ceruloplasmin }\end{array}$ \\
\hline & $\begin{array}{c}\text { Visit } 3 \text { - initiation of } \\
\text { alpha lipoic acid per } \\
\text { os }\end{array}$ & $\begin{array}{l}\text { pain level determination using } \\
\text { the visual analogue pain scale, } \\
\text { vibration perception threshold } \\
\text { using the Rydel-Seiffer fork, } \\
\text { monitoring of adverse effects }\end{array}$ & \\
\hline $\begin{array}{l}\text { Per os treatment } \\
\text { phase }\end{array}$ & Visit 4 & $\begin{array}{c}\text { blood level of lipoperoxids, } \\
\text { blood level of ceruloplasmin, } \\
\text { pain level determination using } \\
\text { the visual analogue pain scale, } \\
\text { vibration perception threshold } \\
\text { using the Rydel-Seiffer fork, } \\
\text { laboratory exam, glycated } \\
\text { hemoglobin, monitoring of } \\
\text { adverse effects }\end{array}$ & \\
\hline
\end{tabular}




\begin{tabular}{|c|c|}
\hline Parameter & Values \\
\hline Number of patients & 24 \\
\hline Sex & 10 women; 14 men \\
\hline Mean age & $56 \pm 9$ years \\
\hline Type of diabetes mellitus & 6 type $1 ; 18$ type 2 \\
\hline Diabetes mellitus history & $8.6 \pm 7.5$ years \\
\hline $\begin{array}{c}\text { Duration of diabetic polyneuropathy } \\
\text { symptoms }\end{array}$ & $2.3 \pm 0.8$ years \\
\hline
\end{tabular}

Table 2. Characteristic of patients with diabetes mellitus

\begin{tabular}{|c|c|}
\hline Parameter & Values \\
\hline Number of patients & 20 \\
\hline Sex & 10 women; 10 men \\
\hline Mean age & $57 \pm 2$ years \\
\hline
\end{tabular}

Table 3. Characteristic of patients with diabetes mellitus

\begin{tabular}{|c|c|c|c|}
\hline Parameter & $\begin{array}{c}\text { Patients } \\
\text { without DM }\end{array}$ & $\begin{array}{c}\text { Patients with DM } \\
\text { Visit 2 }\end{array}$ & $\begin{array}{c}\text { Patients with DM } \\
\text { Visit 4 }\end{array}$ \\
\hline Lipoperoxids $(\mathrm{nmol} / \mathrm{ml})$ & $0.88 \pm 0.14$ & $1.75 \pm 0.2$ & $1.37 \pm 0.4$ \\
\hline
\end{tabular}

Table 4. Mean values of malondyaldehide $(\mathrm{nmol} / \mathrm{ml})$ as an indicator of lipid peroxidation

\begin{tabular}{|c|c|}
\hline & p value \\
\hline Patients without DM vs. patients with DM visit 2 & $p<0.01$ \\
\hline Patients with DM visit 2 vs patients with DM visit 4 & $p<0.01$ \\
\hline Patients without DM vs. patients with DM visit 4 & $p<0.01$ \\
\hline
\end{tabular}

Table 5. Statistical differences concerning the values of lipoperoxides 


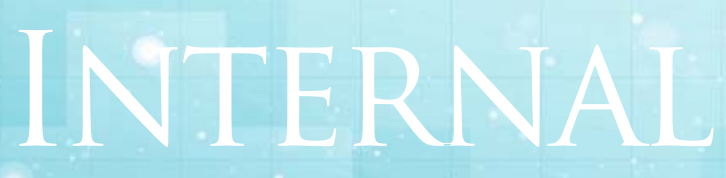

Original papers

The administered medication was alpha lipoic acid. This substance was administered in intravenous perfusion for 10 days and then per os for 30 days. The administration form was perusable solution of $50 \mathrm{ml}$ containing $600 \mathrm{mg}$ of alpha lipoic acid presenting as meglumine salt of alpha lipoic acid $1167.7 \mathrm{mg}$ and excipients.

Alpha lipoic acid administration was started beginning with visit 2 . The solution was administered once daily, slowly for 30 minutes. The treatment was continued for 30 days with alpha lipoic acid tablets. The tablets were given once daily.

For the evaluation of oxidative stress we determined the level of malodyaldehide, expressed in units of malodyaldehide $\mathrm{nmol} / \mathrm{l}$, this being a product of lipoperoxidation, and we also determined the level of ceruloplasmine a protein with antioxidant effect that rises as a response to a high level of oxidative stress.

Statistical analysis was realized with the help of Microsoft Excel software for the descriptive part and the analytical part was performed with the MedCalc software. A value of $p<0.01$ was considered statistically significant.

\section{Results and discussions}

Characteristics of patients with diabetes mellitus and without diabetes mellitus are described in table 2 and 3.
Lipoperoxids values that show the intensity of oxidative stress were statistically significant $(p<0.01)$ greater in patients with diabetes mellitus than in healthy subjects, $1.75 \mathrm{nmol} /$ $\mathrm{ml}$ vs. $0.88 \mathrm{nmol} / \mathrm{ml}$. These values were measures at visit 2 before the diabetes patients began the treatment with alpha lipoic acid.

These results confirm that the intensity of oxidative stress is much higher in the diabetes patients, in this study it was twice as high as in healthy subjects. Oxidative stress is responsible for nerve damage and this is one of the mechanisms implied in diabetic neuropathy pathogenesis. Lipoperoxids determination was then performed at the end of the study after 40 days of therapy with alpha lipoic acid. We observe that the levels of malondyaldeyde diminished from 1.75 $\mathrm{nmol} / \mathrm{ml}$ to $1.37 \mathrm{nmol} / \mathrm{ml}$, a statistically significant decrease.

However the concentration of lipoperoxides remained statistically significant higher in diabetes patients compared to patients without diabetes even after alpha lipoic acid administration. These results show the efficacy of alpha lipoic acid in reducing oxidative stress. Further investigations can be continued to investigate whether a dose increase or a longer duration of treatment further reduce the level of oxidative stress.

Mean value of blood ceruloplasmin in patients with diabetes mellitus, $47.8 \mathrm{mg} / \mathrm{dl}$, 


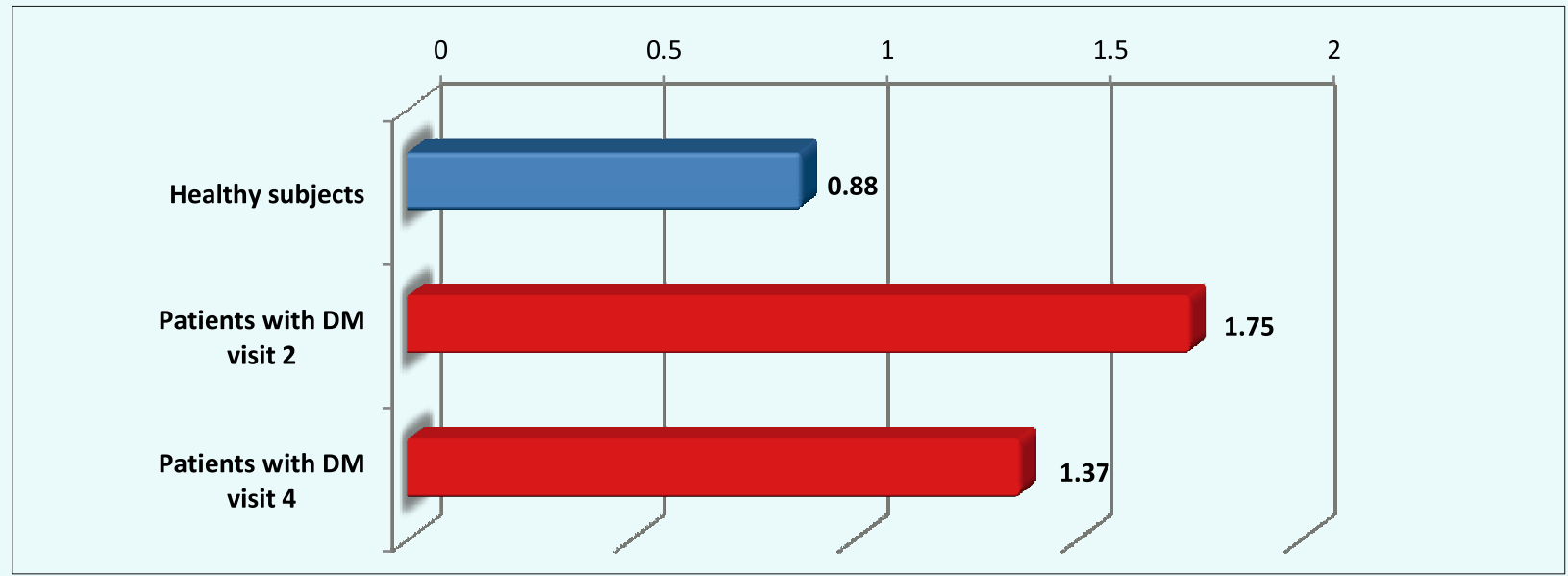

Figure 2. Mean values of lipid peroxidation products expressed as malondyaldehyde nmol/l in healthy subjects, in diabetes mellitus patients before ALA therapy and after end of ALA therapy

\begin{tabular}{|c|c|c|c|}
\hline Parameter & $\begin{array}{c}\text { Patients } \\
\text { without DM }\end{array}$ & $\begin{array}{c}\text { Patients with DM } \\
\text { Visit 2 }\end{array}$ & $\begin{array}{c}\text { Patients with DM } \\
\text { Visit 4 }\end{array}$ \\
\hline Ceruloplasmin (mg/dl) & $30.5 \pm 5.2$ & $47.8 \pm 4.5$ & $43.2 \pm 5.1$ \\
\hline
\end{tabular}

Table 6. Mean values of ceruloplasmin

\begin{tabular}{|c|c|}
\hline & p value \\
\hline Patients without DM vs. patients with DM visit 2 & $\mathrm{p}<0.01$ \\
\hline Patients with DM visit 2 vs patients with DM visit 4 & $\mathrm{p}<0.01$ \\
\hline Patients without DM vs. patients with DM visit 4 & $\mathrm{p}<0.01$ \\
\hline
\end{tabular}

Table 7. Statistical differences concerning the values of ceruloplasmin

\begin{tabular}{|c|c|c|}
\hline Visit & $\begin{array}{c}\text { Pain intensity } \\
\text { on Visual Analogue Scale }\end{array}$ & $\begin{array}{c}\text { Vibration perception } \\
\text { threshold }\end{array}$ \\
\hline V2 & $5.8 \pm 3.2$ & $4.5 \pm 0.2$ \\
\hline V3 & $3.9 \pm 3.4^{*}(p<0.01$ vs. V2) & $5.1 \pm 0.8 *(p<0.01$ vs. V2) \\
\hline V4 & $3.4 \pm 3.1^{* *}(p<0.01$ vs. V3) & $5.7 \pm 0.5^{* *}(p<0.01$ vs. V3) \\
\hline
\end{tabular}

Table 8. Modification of clinical characteristics of diabetic neuropathy after alpha lipoic treatment 


\section{INTERNAL ME}

\section{Original papers}

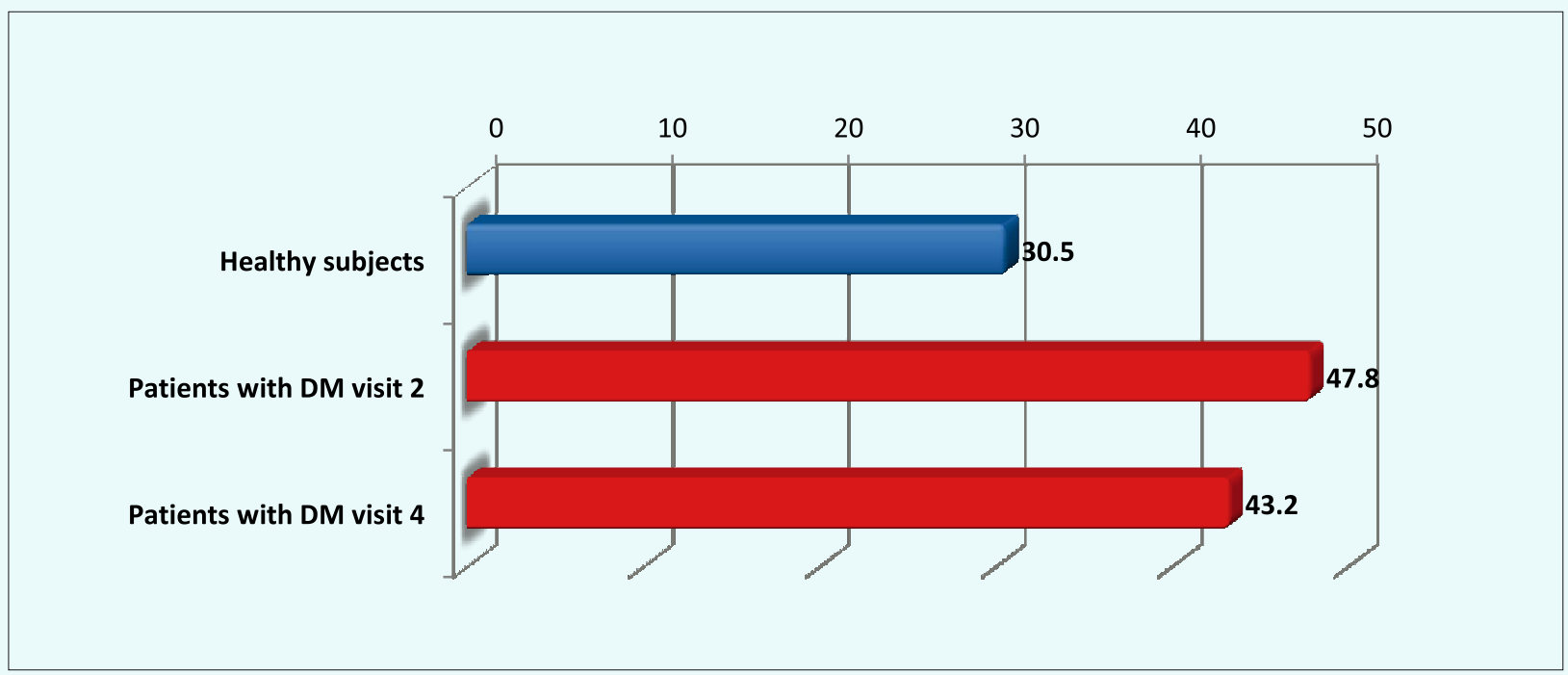

Figure 3. Mean values of ceruloplasmin in healthy subjects, in diabetes mellitus patients before ALA therapy and after end of ALA therapy

\begin{tabular}{|c|c|}
\hline Visit & HbA1C \\
\hline V1 & $8.25 \pm 1.6 \%$ \\
\hline V4 & $8.11 \pm 1.1 \%$ \\
\hline
\end{tabular}

Table 9. HbA1C modification after ALA treatment 
was statistically significant greater than in patients without diabetes mellitus, $30.5 \mathrm{mg} /$ dl. After the treatment with alpha lipoic acid administered intravenously and then by mouth, the mean values of serum ceruloplasmin dropped from $47.8 \mathrm{mg} / \mathrm{dl}$ to $43.2 \mathrm{mg} / \mathrm{dl}$, the decrease being statistically significant.

However, the ceruloplasmin levels remained statistically significant higher in patients with diabetes mellitus even after the administration of alpha lipoic acid compared to the values in healthy subjects.

After administration of alpha lipoic acid intravenously the pain intensity on the visual analogue scale was lower, the difference being statistically significant $(p<0.01)$.

Vibration perception threshold after alpha lipoic acid administration intravenously increased statistically significant $(p<0.01)$. These modifications were recorded at visit 3 after the end of alpha lipoic acid therapy administered intravenously for 10 days. The clinical profile of diabetic neuropathy continued to improve after 30 days of alpha lipoic acid administration by mouth.

After 40 days of therapy with alpha lipoic acid, 10 days intravenously and 30 days per os, the glycated haemoglobin did not decrease statistically significant $(p>0.05)$, which demonstrates that the improvement in the oxidative stress parameters and clinical characteristic of diabetic neuropathy cannot be attributed to glycaemic control improvement.

Alpha lipoic acid was effective in decreasing oxidative stress as resulted in our study because it is a substance that increases reduced glutathione a substance that is produced in the body ${ }^{(7)}$. Also alpha lipoic acid acts as free radical scavenger ${ }^{(7)}$. There are numerous studies that confirm that alpha lipoic acid is effective in reducing diabetic neuropathy symptoms, one study demonstrated that treatment with ALA for 5 weeks administered per os decreased neuropathy symptoms and the study established the optimum dose of $600 \mathrm{mg}$ alpha lipoic acid per day ${ }^{(8)}$.

A meta-analysis of studies concerning the efficacy of alpha lipoic acid therapy concludes that intravenous treatment produces significant improvement in painful diabetic neuropathy while oral treatment seems to be less effective ${ }^{(9)}$. In our study improvement in pain symptoms and vibration perception threshold continued after ending the intravenous therapy, starting the oral therapy and after its completion evaluating neuropathy characteristic. These results demonstrate that improvements in diabetic neuropathy achieved by intravenous ALA therapy can be maintained and further improved by starting ALA therapy per os.

\section{Conclusion}

Patients with diabetes mellitus have an increased level of oxidative stress compared with people with normal glucose metabolism. In our study the level of oxidative stress as measured by lipoperoxids production was twice as high. Alpha lipoic acid produced a significant reduction in oxidative stress parameters, a decrease that lead to a significant improvement in pain intensity and vibration perception threshold in patients with painful diabetic neuropathy.

\section{References}

1. Bansal, V, J Kalita, and U K Misra. "Diabetic Neuropathy." Postgraduate Medical Journal 82.964 (2006): 95-100. PMC. Web. 27 June 2018.

2. Juster-Switlyk, Kelsey, and A. Gordon Smith. "Updates in Diabetic Peripheral Neuropathy." F1000Research 5 (2016): F1000 Faculty Rev-738. PMC. Web. 27 June 2018. 3. Román-Pintos, Luis Miguel et al. "Diabetic Polyneuropathy in Type 2 Diabetes Mellitus: 


\section{INTERNAI Original papers}

Inflammation, Oxidative Stress, and Mitochondrial Function." Journal of Diabetes Research 2016 (2016): 3425617. PMC. Web. 27 June 2018.

4. Antonio Ayala, Mario F. Muñoz, and Sandro Argüelles, "Lipid Peroxidation: Production, Metabolism, and Signaling Mechanisms of Malondialdehyde and 4Hydroxy-2-Nonenal," Oxidative Medicine and Cellular Longevity, vol. 2014, Article ID 360438, 31 pages, 2014

5. Mahreen, Rashida et al. "Significantly Increased Levels of Serum Malonaldehyde in Type 2 Diabetics with Myocardial Infarction." International Journal of Diabetes in Developing Countries 30.1 (2010): 49-51. PMC. Web. 27June 2018.

6. Shay, Kate Petersen et al. "Alpha-Lipoic Acid as a Dietary Supplement: Molecular Mechanisms and
Therapeutic Potential." Biochimica et biophysica acta 1790.10 (2009): 1149-1160. PMC. Web. 27 June 2018.

7. Vallianou, Natalia, Angelos Evangelopoulos, and Pavlos Koutalas. "Alpha-Lipoic Acid and Diabetic Neuropathy." The Review of Diabetic Studies : RDS 6.4 (2009): 230-236. PMC. Web. 30 June 2018.

8. Ziegler D, Ametov A, Barinov A, Dyck PJ, Gurieva I, Low PA, Munzel U, Yakhno N, Raz I, Novosadova M. et al. Oral treatment with alpha-lipoic acid improves symptomatic diabetic polyneuropathy. The SYDNEY 2 trial. Diabetes Care. 2006;29:2365-2370.

9. Mijnhout GS, Alkhalaf A, Kleefstra N, Bilo HJ, Alpha lipoic acid: a new treatment for neuropathic pain in patients with diabetes?, Neth J Med. 2010 Apr;68(4):158-62. 